\title{
Strategi Komunikasi Persuasi Sales and Account Manager dalam Mempertahankan Pelanggan
}

\author{
Vina Dartina \\ Program studi Ilmu Komunikasi, Pascasarjana Universitas Islam Bandung, \\ Jl. Purnawarman No. 59 Bandung - 40116. \\ Email:vina.dartina@gmail.com
}

\begin{abstract}
High business competition both in domestic market and international market demands company to work harder in defending company's life. A sales and account manager of PT ISS west Java has a full response to make sure that the customers keep using their service. This research aims at figuring some objectives such as to know and to analyze the importance of persuasive communication usage for Sales and Account Manager in defending the customers, to know and to analyze persuasive communication techniques of Sales and Account Manager, to know and to analyze the distraction and solution of Sales and Account Manager in doing persuasive communication to defend the customers using qualitative method through case study approach. This research used social interaction theory. The results of the research showed that Sales and Account Manager comprehends the importance of persuasive communication usage in defending the customers which concerns on utensils and persuasive techniques as well as message arrangement. The distractions happen when Sales and Account Manager does the persuasive communication with the customers are timing, internal and external distractors, and psychological distraction from both sides. To cope the distractions, there are several ways and NOSE methods.
\end{abstract}

Keywords: Persuasive Communication, Defending Customer, Utensils, Technique, and Persuasive Message.

\begin{abstract}
Abstrak. Kompetisi bisnis yang semakin ketat baik di pasar domestik maupun internasional menuntut perusahaan untuk bekerja lebih keras dalam mempertahankan pelanggan. Seorang Sales and Account Manager di PT ISS Jawa Barat bertanggung jawab penuh untuk memastikan agar pelanggan terus menggunakan jasa dalam bisnis mereka. Strategi komunikasi persuasi merupakan komponen penting dalam suatu upaya mempertahankan pelanggan. Penelitian ini bertujuan untuk mengetahui dan menganalisis pentingnya penggunaan komunikasi persuasi bagi Sales and Account Manager dalam mempertahankan pelanggan, mengetahui dan menganalisis perangkat persuasi yang dilakukan oleh Sales and Account Manager, mengetahui dan menganalisis teknik komunikasi persuasi yang dilakukan oleh dalam Sales and Account Manager, mengetahui dan menganalisis hambatan dan solusi yang dialami oleh Sales and Account Manager. Metode penelitian yang digunakan adalah metode kualitatif dengan pendekatan studi kasus. Teori dalam penelitian ini adalah teori interaksi sosial. Hasil penelitian menunjukan bahwa Sales and Account Manager memahami pentingnya penggunaan komunikasi persuasi dalam mempertahankan pelanggan dengan mengacu pada perangkat dan teknik persuasi serta penyusunan pesan yang digunakan. Hambatan yang terjadi ketika Sales and Account Manager melakukan komunikasi persuasi dengan pelanggan adalah terkait hambatan internal dan ekternal, hambatan psikologis dari kedua belah pihak. Untuk mengatasi hambatan tersebut dilakukan berbagai cara serta menggali NOSE.
\end{abstract}

Kata kunci: Komunikasi Persuasi, Mempertahankan Pelanggan, Perangkat, Teknik, dan Pesan Persuasi. 


\section{Pendahuluan}

Kompetisi bisnis yang semakin ketat baik di pasar domestik maupun internasional menuntut perusahaan untuk bekerja lebih keras dalam mempertahankan kelangsungan hidup perusahaannya, selain untuk terus meningkatkan penjualan dan laba, salah satu cara yang digunakan perusahaan dalam mempertahankan kelangsungan hidupnya adalah dengan mempertahankan pelanggan. Pelanggan merupakan aspek yang sangat penting bagi perusahaan, sehingga setiap perusahaan sangat berharap untuk dapat mempertahankan pelanggannya dalam jangka panjang, bahkan jika mungkin untuk selamanya.Mempertahankan pelanggan bukanlah suatu hal yang mudah terlebih jika menghendaki prosesnya berlangsung secara instan.

Konsumen yang semakin kritis dalam memilih dan menentukan produk ataupun jasa menuntut perusahaan untuk saling berpacu dalam melakukan berbagai strategi guna mempertahankan pelanggan. Ketidakmampuan perusahaan merespon persaingan atau kondisi pasar yang ada secara tepat dapat mengakibatkan hilangnya pelanggan. Sehingga isu penting yang dihadapi perusahaan-perusahaan saat ini adalah bagaimana perusahaan tersebut mempertahankan dan menarik pelanggan agar tetap loyal dan bertambah. Metode yang biasanya digunakan dalam kegiatan usaha ataupun penjualan, baik produk ataupun jasa adalah dengan melakukan komunikasi persuasi. Hal ini ditegaskan oleh Widjaja (2002: 67) yang mengatakan bahwa "komunikasi persuasi ini tidak lain dari pada suatu usaha untuk meyakinkan orang lain agar publiknya berbuat dan bertingkah laku seperti yang diharapkan komunikator dengan membujuk tanpa memaksanya atau tanpa kekerasan".Komunikasi persuasi banyak dimanfaatkan dalam kegiatan pemasaran, baik saat menawarkan produk, maupun dalam kaitan mempertahankan pelanggan.

Dari pemaparan yang telah dijelaskan tersebut, dapat dinyatakan bahwa seorang Sales and Account Manager tidak cukup hanya memiliki kompetensi yang berisikan kemampuan menjual dan pengetahuan produk yang memadai saja, karena seorang Sales and Account Manager akan berhadapan dengan situasi yang sering kali tidak sesuai dengan harapan mereka. Kemampuan berkomunikasi secara persuasif akan membuka peluang dari setiap kesempatan dan kondisi yang tidak kondusif yang akan dihadapi seorang sales atau tenaga penjual. Lebih lanjut dapat dikatakan bahwa komunikasi persuasi yang digunakan oleh seorang Sales and Account Manager harus berfungsi untuk membangun partnerships, sumber daya intelektual, mempromosikan satu gagasan, suatu produk, servis, atau suatu organisasi, dengan sasaran untuk menciptakan nilai bagi bisnis yang dijalankan. Merujuk pada pemaparan sebelumnya tentang pentingnya mempertahankan pelanggan melalui komunikasi persuasi Sales and Account Manager, maka penelitian ini akan dilakukan di PT ISS Cabang Jawa Barat yang berhasil meraih penghargaan Brand Improvement yang menandakan minimnya pelanggan yang putus kontrak pada cabang tersebut atau bisa disebut Customer Retention Rate rendah. Dalam penelitian ini peneliti melihat permasalahan bagaimana komunikasi persuasi yang dilakukan Sales and Account Manager PT ISS Jawa Barat dalam mempertahankan pelangan?

Tujuan penelitian ini adalah untuk mengetahui dan menganalisis 
pentingnya penggunaan komunikasi persuasi bagi Sales and Account Manager dalam mempertahankan pelanggan, perangkat persuasi yang dilakukan oleh Sales and Account Manager PT ISS Jawa Barat dalam mempertahankan pelanggan, teknik komunikasi persuasi yang dilakukan oleh Sales and Account Manager PT ISS Jawa Barat dalam mempertahankan pelanggan, serta Hambatan dan solusi yang dialami oleh Sales and Account Manager ketika melakukan komunikasi persuasi dalam mempertahankan pelanggan.

Terkait dengan maksud peneliti untuk mengungkap Strategi Komunikasi Persuasi Sales and Account Manager dalam mempertahankan pelanggan, maka yang dijadikan teori sebagai pendamping peneliti adalah teori interaksi sosial yang peneliti anggap mewakili konteks persuasi seorang Sales and Account Manager di PT ISS Jawa Barat. Interaksi sosial merupakan hubungan sosial yang dinamis yang menyangkut hubungan antar orang perorangan, antar kelompok-kelompok manusia dan antar orang dengan kelompok-kelompok masyarakat. Interaksi terjadi apabila dua orang atau kelompok saling bertemu dan pertemuan antara individu dengan kelompok dimana komunikasi terjadi diantara kedua belah pihak (Yulianti, 2003: 91).

\section{Metode}

Metode penelitian yang digunakan dalam penelitian ini adalah metode penelitian kualitatif. Metode kualitatif adalah suatu metode dimana manusia atau responden dianggap sebagai mahluk aktif yang selalu dinamis, angket tidak perlu dipola dan harus mengadakan wawancara langsung yang tidak berstruktur atau tidak berpedoman, populasinya kecil, dan tidak berlaku generalisasi karena tidak semua individu manusia itu sama (Mulyana, 2001:145). Sesuai dengan judul yang peneliti angkat, yaitu "Strategi Komunikasi Persuasi Sales and Account Manager Dalam Mempertahankan Pelanggan", maka metode yang peneliti gunakan adalah metode kualitatif. Hal ini dikarenakan data yang diperoleh tidak dilakukan dengan prosedur statistik, dan data tidak berwujud angka melainkan suatu mutu atau kualitas, prestasi, tingkat dari semua variable penelitian yang biasanya tidak bisa dihitung atau diukur secara langsung.

Melalui metodologi kualitatif, penelitian ini menggunakan pendekatan sebagai bentuk metode yang tepat digunakan dalam proses penelitian. Pendekatan yang digunakan dalam penelitian ini adalah studi kasus. Studi kasus merupakan strategi penelitian dimana didalamnya peneliti menyelidiki secara cermat suatu program, peristiwa, aktivitas, proses, atau sekelompok individu. Kasus-kasus dibatasi oleh waktu dan aktivitas, dan peneliti mengumpulkan informasi secara lengkap dengan menggunakan berbagai prosedur pengumpulan data berdasarkan waktu yang telah ditentukan (Stake, 1995 dalam Creswell 2010:20).

Penulis menggunakan pendekatan studi kasus dalam penelitian ini di mana secara umum, studi kasus merupakan strategi yang lebih cocok apabila pokok pertanyaan suatu penelitian berkenaan dengan how (bagaimana) dan why (mengapa), bila peneliti memiliki sedikit peluang untuk mengontrol peristiwa-peristiwa yang akan diselidiki dan bilamana fokus penelitiannya terletak pada fenomena kontemporer (masa kini) di dalam konteks kehidupan nyata (Yin, 2002:1).

Paradigma yang digunakan pada penelitian ini, yaitu paradigma konstruktivisme. Makna yang dikonstruk secara individual merupakan 


\section{2 | Vina Dartina}

pendorong substantif bagi pembentukan kesan dan proses persepsi orang yang bersangkutan (Kaye, 1994:41). Dalam menjelaskan paradigma konstruktivisme, realitas sosial merupakan konstruksi sosial yang diciptakan oleh individu, individu adalah manusia bebas yang melakukan hubungan antara manusi yang satu dengan yang lainnya. Individu menjadi penentu dalam dunia sosial yang dikonstruksi sesuai dengan kehendaknya. Individu bukanlah korban fakta sosial, namun sebagai mesin produksi sekaligus reproduksi yang kreatif dalam mengkonstruksi dunia sosialnya. (Yuningsih, dalam Mediator 2006: 61).

Teknis yang digunakan dalam meneliti adalah wawancara mendalam, dan untuk mendapatkan data terkait subjek penelitian yang dijadikan sebagai informan dalam penelitian ini adalah Sales and Account Manager, Branch Business Manager, Service Manager, dan Pelanggan. Sesuai dengan judul penelitian yakni Strategi Komunikasi Persuasi Sales and Account Manager Dalam Mempertahankan Pelanggan, maka objek dalam penelitian ini adalah Komunikasi Persuasi yang dilakukan oleh Sales and Account Manager tersebut. Oleh karena itu, objek penelitian ini merupakan penjabaran secara mendalam melalui wawancara kepada pihak-pihak yang terkait dan observasi di lapangan sebagai bentuk pencarian informasi mendetail sehubungan dengan segala hal yang terdapat dalam kegiatan komunikasi persuasi, termasuk diantaranya adalah mengenai teknik persuasi, perangkat persuasi serta mengapa komunikasi persuasi itu penting untuk dilakukan dalam mempertahankan pelanggan, sedangkan yang menjadi tempat dalam penelitian ini adalah PT ISS Jawa Barat.

\section{Temuan dan Pembahasan}

Pelaksanaan komunikasi
persuasi yang dilakukan Sales and
Account $\begin{gathered}\text { Manager } \\ \text { dalam }\end{gathered}$
mempertahankan pelanggan sudah
cukup baik, terbukti dengan hasil
penelitian literatur, wawancara dan
observasi yang penulis lakukan terlihat
bahwa Sales and Account Manager
sudah memahami artinya komunikasi
persuasi. Pada pelaksanaan upaya
mempertahankan pelanggan pun hampir
dapat dipastikan menggunakan
komunikasi persuasi. Hasil yang didapat
dari penggunaan komunikasi persuasi
ini membawa hasil yang diinginkan,
yakni terciptanya sebuah kondisi
dimana pelanggan tetap menggunakan
jasa layanan ISS dan terus melanjutkan
kontrak kerjasama.

\section{Analisis pentingnya penggunaan komunikasi persuasi dalam mempertahankan pelanggan.}

Hasil wawancara penulis dengan para pihak terkait di PT ISS Jawa Barat juga membuktikan adanya manfaat yang besar sehingga menjadikan komunikasi persuasi sebagai komunikasi paling dominan yang dipakai untuk mempertahankan pelanggan. Sebagai ujung tombak dalam menghadapi pelanggan, kemampuan berkomunikasi seorang Sales and Account Manager sangat dipertaruhkan, bagaimana tidak, pada pelaksanaan mempertahankan pelanggan, komunikasi persuasi menjadi salah satu alat yang wajib dilakukan. Sejalan dengan hasil analisis tersebut, akan digambarkan dalam model di bawah ini. 


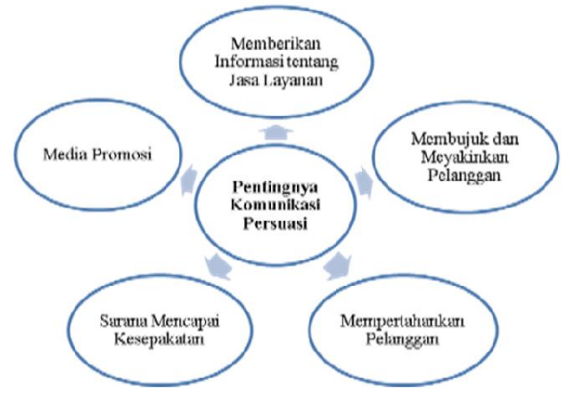

Gambar 1. Model pentingnya komunikasi persuasi dalam mempertahankan pelanggan

Sumber: Hasil olah data peneliti

\section{Analisis perangkat persuasi dalam mempertahankan pelanggan.}

Perangkat persuasi merupakan bagian kegiatan persuasi yang dilakukan oleh Sales and Account Manager. Perangkat ini dimulai dari reciprocation yang berarti menganut prinsip kebaikan dibalas kebaikan, komitmen dan konsistensi, pembuktian sosial, rasa suka, otoritas, dan kelangkaan. Dari hasil analisis, peneliti telah membuat ragam model yang sesuai, yaitu sebagai berikut.

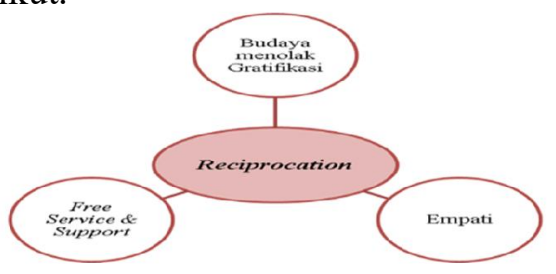

Gambar 2. Model perangkat persuasi reciprocation dalam mempertahankan pelanggan

Sumber: Hasil olah data peneliti.

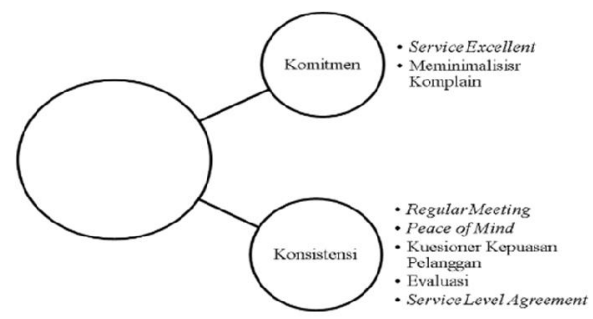

Gambar 3. Model perangkat persuasi komitmen dan konsistensi dalam mempertahankan pelanggan Sumber: Hasil olah data peneliti

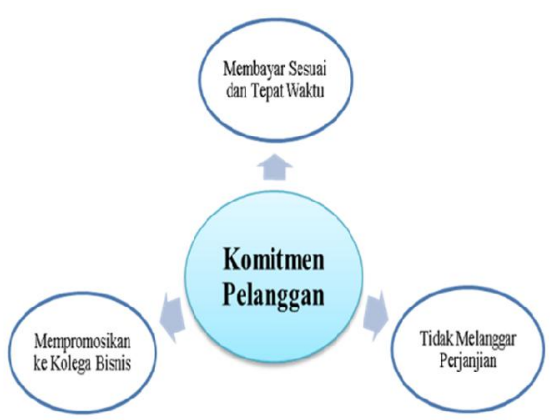

Gambar 4. Model perangkat persuasi komitmen pelanggan terhadap PT ISS Jawa Barat Sumber: Hasil olah data peneliti.

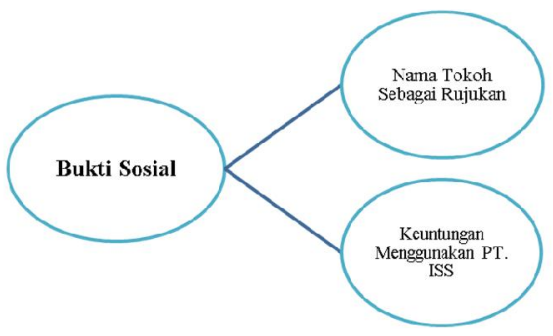

Gambar 5. Model perangkat persuasi bukti sosial dalam mempertahankan pelanggan

Sumber: Hasil olah data peneliti

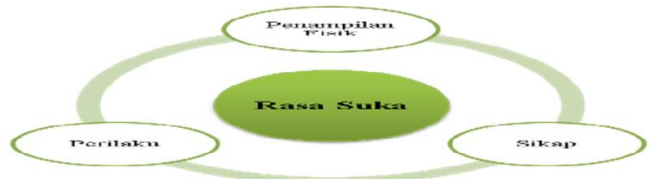

Gambar 6. Model perangkat persuasi rasa suka dalam mempertahankan pelanggan

Sumber: Hasil olah data peneliti 


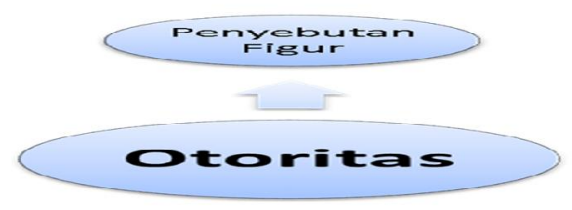

Gambar 7. Model perangkat persuasi otoritas dalam mempertahankan pelanggan

Sumber: Hasil olah data peneliti

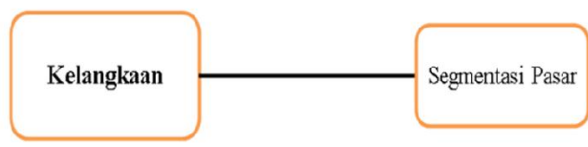

Gambar 8. Model perangkat persuasi kelangkaan dalam mempertahankan pelanggan

Sumber: Hasil olah data peneliti

Dari pemaparan analisis terkait dengan perangkat persuasi yang dilakukan oleh Sales and Account Manager dalam mempertahankan pelanggan, dapat digambarkan dalam model berikut di bawah ini.

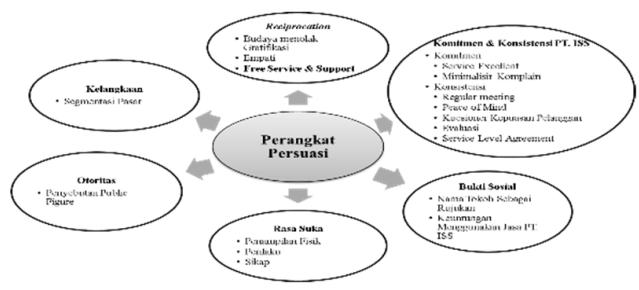

Gambar 9. Model perangkat persuasi dalam mempertahankan pelanggan

Sumber: Hasil olah data peneliti

\section{Analisis teknik komunikasi persuasi dalam mempertahankan pelanggan}

Dari hasil wawancara yang dilakukan, peneliti dapat menyimpulkan bahwa saat melakukan komunikasi persuasi kepada pelanggan, Sales and
Account Manager telah melakukan beberapa teknik persuasi. Seringkali teknik tersebut tidak direncanakan sebelumnya, akan tetapi mengalir begitu saja dan bersifat situasional serta kondisional.

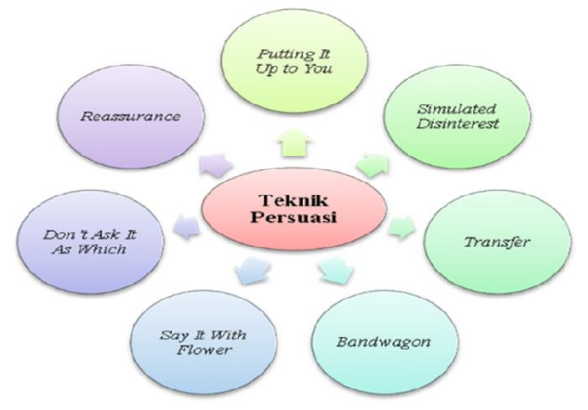

Gambar 10. Model teknik persuasi dalam mempertahankan pelanggan

Sumber: Hasil olah data peneliti

Sejalan dengan temuan peneliti tentang teknik persuasi yang dilakukan oleh Sales and Account Manager, tentunya tidak dapat dipisahkan dengan pesan yang digunakan, karena pesan merupakan bagian dari teknik persuasi. Dalam mengembangkan pesan pada teknik persuasi, ada beberapa hal yang perlu diperhatikan yakni ragam pesan, cara menyampaikan pesan, intonasi, dan lain sebagainya.

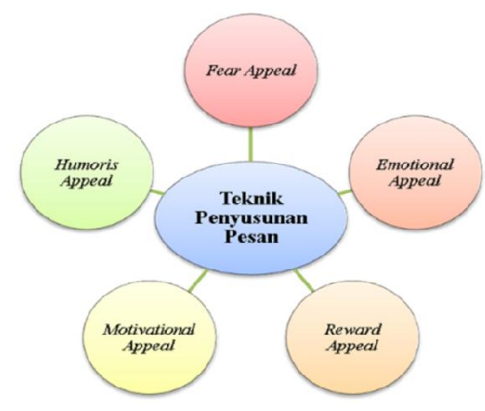

Gambar 11. Model pesan dalam teknik persuasi dalam mempertahankan pelanggan

Sumber: Hasil olah data peneliti. 
Dari pemaparan hasil analisis terkait teknik persuasi dan pesan persuasi yang digunakan, dapat dilihat dalam model gambar di bawah ini.

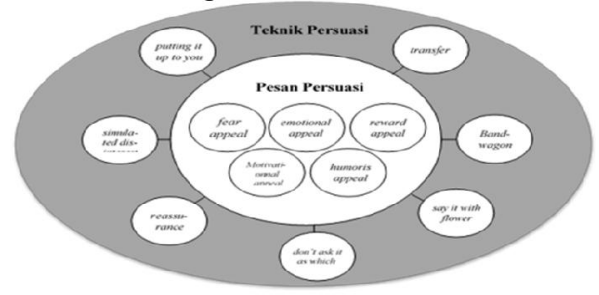

Gambar 12. Model pesan dalam teknik persuasi dalam mempertahankan pelanggan

\section{Analisis hambatan dan solusi dalam mempertahankan pelanggan}

Dari hasil wawancara yang peneliti lakukan dengan narasumber, peneliti dapat menyimpulkan bahwa hambatan yang terjadi ketika Sales and Account Manager melakukan komuniksi persuasi dalam mempertahankan pelanggan adalah terkait dengan waktu, kondisi psikologis Sales and Account Manager atau pun mood dari pelanggan itu sendiri. Merujuk pada hambatan yang terjadi ketika Sales and Account Manager tengah melakukan komunikasi persuasi untuk mempertahankan pelanggan yang telah dikemukakan diatas, dari hasil wawancara peneliti menemukan solusi atas hambatan-hambatan tersebut. Solusi pertama yang dapat dilakukan adalah memerhatikan ketepatan waktu. Sales and Account Manager harus lebih teliti dan detail terkait dengan waktu dilaksanakannya komunikasi persuasi terhadap pelanggan. Solusi bagi hambatan kedua terkait kondisi psikologis Sales and Account Manager dan mood pelanggan adalah melalui cara melatih kondisi psikologis Sales and Account Manager itu sendiri. Selain mengingat akan tujuan yang ingin dicapai, seorang Sales and Account
Manager pun peneliti lihat mampu sangat antusias untuk melatih mental agar dapat menaklukan kondisi psikologisnya dan menghadapi pelanggan secara profesional.

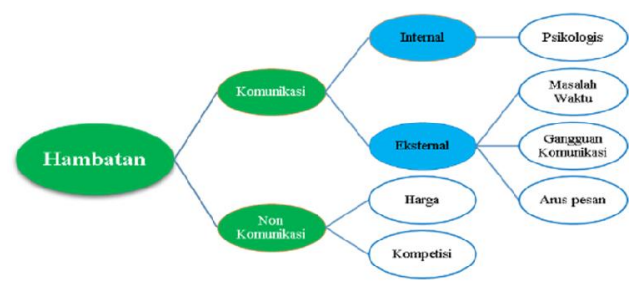

Gambar 13. Model hambatan dan solusi dalam mempertahankan pelanggan

Sumber: Hasil olah data peneliti

\section{Pembahasan}

\section{Pentingnya penggunaan komunikasi persuasi dalam mempertahankan pelanggan}

Manfaat dari komunikasi persuasi sebetulnya sudah banyak diketahui orang. Tidak hanya di kehidupan sehari-hari atau pun pergaulan, komunikasi persuasi pun banyak dilakukan dalam kegiatan di dunia bisnis, termasuk dalam aspek yang terkait dengan kegiatan pemasaran. Komunikasi persuasi bukanlah hal yang mudah, banyak faktor yang harus dipertimbangkan agar komunikan mau merubah sikap, pendapat, dan perilakunya.

Kemampuan berkomunikasi secara persuasif dari seorang Sales Account Manager merupakan hal penting yang harus dipilih perusahaan dalam menyusun strategi penjualan, termasuk juga dalam mempertahankan pelanggan. Hal ini tentunya dikarenakan poin penting dari keberadaan kemampuan berkomunikasi adalah memberikan informasi yang sangat dibutuhkan oleh Sales Account 
Manager agar dapat menyesuaikan dan mengendalikan situasi yang sedang dihadapi dengan langkah dan pendekatan yang sesuai.

\section{Perangkat persuasi dalam mempertahankan pelanggan}

\section{Reciprocation}

Reciprocation ini menganut prinsip kebaikan dibalas kebaikan, dengan kata lain jika diimplementasikan pada upaya yang dilakukan Sales and Account Manager untuk mempertahankan pelanggan, maka Sales and Account Manager akan memberikan sebuah kebaikan dengan harapan kebaikan tersebut dibalas oleh pelanggan melalui cara tetap menjadi pelangggan ISS Jawa Barat. Kebaikan yang dilakukan oleh Sales and Account Manager bukan berupa uang ataupun iming-iming bersifat materi lainnya. Hal ini dikarenakan adanya Pakta Integritas yang telah ditandatangi, yang berisikan anti suap. Setiap karyawan dilarang memberikan atau menerima uang dalam jumlah berapapun kepada pelanggan.

\section{Komitmen Dan Konsistensi}

Seorang Sales Account Manager di PT ISS Indonesia harus mampu menerjemahkan dan mengirimkan pesan-pesan yang terangkum dalam misi dan aspirasi pada pelanggan ini dengan tepat dan efektif, penuh komitmen serta konsisten. Karena hal tersebut merupakan sebuah janji yang harus ditepati. Artinya, apa yang disampaikan kepada pelanggan pada penawaran di awal haruslah sama dengan realita di lapangan. Hal ini juga tidak lepas dengan peranan komunikasi yang dijalankan antara Sales Account Manager dengan para pihak Operasional, dimana di dalamnya terdapat sebuah koordinasi dan kolaborasi.
Proses komunikasi persuasi yang dilakukan oleh Sales and Account Manager kepada pelanggan pun harus dilakukan secara konsisten. Artinya langkah-langkah yang dilakukan harus stabil, kontinyu, berkesinambungan. Hal ini dimaksudkan agar pelanggan terus menerus berpandangan positif terhadap ISS Jawa Barat dan tidak pindah pada vendoor lain. Jika upaya persuasi ini tidak dilakukan secara konsisten, maka akan ada kemungkinan pelanggan tersebut berubah pikiran atau tidak merasa dianggap dan kecewa. Tetapi dari hasil temuan penelitian yang penulis dapatkan melalui wawancara dan observasi di lapangan, Sales and Account Manager melakukan komunikasi persuasi kepada pelanggan secara konsisten dengan menemui pelanggan secara langsung maupun melalui telepon.

\section{Bukti Sosial}

Kondisi pelanggan yang merasa bingung untuk melanjutkan atau memutus kontrak kerjasama merupakan ancaman besar bagi PT ISS Jawa Barat. Berdasarkan hasil wawancara dengan ketiga Narasumber dari PT ISS Jawa Barat, didapat informasi bahwa ketiganya pernah menemukan kondisi dimana pelanggan nampak merasa bingung harus meneruskan kerjasama, memutus kerjasama atau memperpanjang kontrak kerjasama. Biasanya Sales and Account Manager dan Tim melakukan pembuktian sosial. Pembuktian sosial ini bisa melalui tokoh ataupun pelanggan yang lain. Bukti sosial yang dilakukan merupakan cara yang cukup kreatif dan meyakinkan pelanggan. Karena sebagai pelanggan yang berada pasa posisi leluasa untuk memilih dan menetukan, mereka sangat perlu untuk diarahkan.

Selain dari bukti sosial melalui penyebutan nama tokoh penting atau pelanggan yang terkait dengan ISS, 
berita-berita positif mengenai ISS di media dapat juga menjadi sarana pembuktian sosial.

\section{Rasa Suka}

ISS sebagai perusahaan pelayanan jasa facility management terbesar di dunia telah mengembangkan sebuah program standar bagi seluruh cabang ISS dimanapun. Standar yang dimaksud bukan hanya terkait dengan standar kerja, melainkan juga melalui value system yang telah menjadi budaya mengakar bagi seluruh karyawannya. Value system ini terpancar pada penampilan, perilaku dan sikap keseharian karyawan. Penampilan secara fisik pun tidak luput dari perhatian ISS. Seluruh karyawan diwajibkan untuk mengenakan seragam sesuai dengan aturan dan jabatan masing-masing.

\section{Otoritas}

Pada PT ISS, penggunaan otoritas sebagai salah satu perangkat persuasi dilakukan jika mendapati situasi yang mengharuskan penyebutan nama atau tokoh seseorang guna memudahkan jalannya persuasi agar tujuan yang dimaksud yakni mempertahankan pelanggan tercapai.Pada perangkat persuasi otoritas ini, Sales and Account Manager telah sesuai dan tepat untuk memlih Elisa Lumbantoruan sebagai tokoh yang dianggap memiliki otoritas dan dijadikan nama rujukan saat melakukan persuasi kepada pelanggan. Nama baik dan nama besar Elisa Lumbantoruan seolah menjadi jaminan yang dapat meyakinkan pelanggan untk tetap bertahan dan meneruskan kontrak kerjasama.

\section{Kelangkaan}

Dari analisis temuan penelitian yang telah dipaparkan sebelumnya, beberapa tahun yang lalu, para Manpower dari ISS sangat sering ditemui pada beberapa mall-mall besar dan rumah sakit di Jawa Barat yang memercayakan pengelolaan gedungnya pada ISS. Belakangan ini, kehadiran ISS di beberapa mall besar dan public venue lainnya dirasa berkurang. Menurut Sales and Account Manager, rupanya hal tersebut bukan hal yang disengaja, akan tetapi bermula dari adanya perubahan segmen target pasar. Lebih lanjut ia menjelaskan bahwa saat ini ISS tidak lagi bicara mengenai brand image, tapi lebih kepada perusahaan atau pelanggan dengan kondisi good payment atau good governanve dan good government.

\section{Teknik komunikasi persuasi dalam mempertahankan pelanggan}

Dalam menguasai teknik persuasi, seorang Sales and Account Manager harus dapat menguasai keterampilan dan kemampuan dasar berkomunikasi. Untuk hal tersebut, seorang Sales and Account Manager harus mampu berfikir dalam frame of reference atau kerangka acuan yang lebih besar agar dapat menggunakan teknik persuasi yang tepat dalam suatu keadaan tertentu. Hal ini dimaksudkan agar tenik persuasi yang digunakan tersebut dapat menyebabkan orang bersedia melakukan sesuatu dengan senang hati, dengan suka rela dan tanpa merasa dipaksa oleh siapapun. Teknik yang digunakan umumnya berbeda dari satu kondisi dengan kondisi lainnya, tergantung pada situasi yang terjadi saat itu.

Berbicara mengenai teknik persuasi, pesan-pesan yang disampaikan oleh Sales and Account Manager tentu 
tidak dapat dipisahkan dari pesan verbal dan pesan nonverbal. Kedua pesan ini saling berkaitan satu sama lain dan memiliki aspek yang sama penting. Sejalan dengan pemaparan tersebut, terkait teknik pesrsuasi yang dilakukan, tedapat hal yang juga tida dapat diabaikan yakni metode penyusunan pesan. Cangara (2004:113) menyebutkan bahwa terdapat beberapa cara yang dapat digunakan dalam penyusunan pesan yang digunakan dalam teknik persuasi, antara lain adalah fear appeal, emotional appeal, reward appeal, motivational appeal, dan humouris appeal.

\section{Hambatan dan solusi komunikasi persuasi dalam mempertahankan pelanggan}

Hambatan yang terjadi ketika Sales and Account Manager melakukan komunikasi persuasi adalah hambatan internal dan ektsternal. Hambatan internal ini terkait dengan kondisi psikologis atau mood dari salah satu atau kedua belah pihak. Senada dengan hambatan komunikasi tersebut, Fisher (1975 dalam Soemirat, 2014:9.2) menjelaskan bahwa "pada prinsipnya, hambatan komunikasi dapat disebabkan oleh dua faktor, yakni faktor mekanistis komunikasi manusia dan faktor psikologis. Hambatan komunikasi persuasi secara mekanistis disebabkan oleh arus pesan pada saluran komunikasi yang terbatas, terganggu, tercemar, atau bahkan dalam kondisi yang rusak. Masalahnya dapat disebabkan oleh faktor internal penerima, misalnya salah tafsir terhadap pesan yang disampaikan atau faktor eksternal, misalnya hasutan-hasutan, isu-isu, gosip-gosip tentang persuader, atau tentang isi pesan itu sendiri). Sedangkan hambatan psikologis, lebih bersifat internal dan indikasinya adalah adanya distorsi makna dari pesan yang disampaikan. Hal ini dapat disebabkan oleh bias kultur, konflik peran, konflik dalam sistem sosial, dan lain-lain. Dengan kata lain, hambatan psikologis ini disebabkan oleh ketidakcocokan filter konseptual dalam diri peserta komunikasi persuasi.

Dari hasil temuan dan analisis wawancara yang peneliti lakukan, untuk hambatan lainnya yang terjadi di lapangan adalah terkait dengan waktu. Jika dibiarkan, tentunya hal ini dapat menjadi masalah yang serius, sehingga untuk mengatasinya Sales and Account Manager seringkali berdiskusi dengan tim operasional di lapangan agar mendapatkan informasi lebih detail tentang kesediaan dan keluangan waktu yang dimiliki oleh pelanggan.

Berbicara mengenai hambatan yang terjadi, tentunya akan diimbangi pula oleh solusi yang dilakukan. Bagi Sales and Account Manager, hambatan yang terjadi ketika dirinya sedang melakukan komunikasi persuasi bukanlah sebuah akhir, melainkan tantangan untuk dicari jalan keluar. Dalam proses pencarian solusi tersebut, Sales and Account Manager selalu melakukan koordinasi dengan atasan dan mitra kerja. Selain dari paparan mengenai solusi yang dikemukakan diatas, dari hasil wawancara dan observasi peneliti menemukan sebuah metode penggalian informasi mengenai pelanggan. Peneliti menyimpulkan bahwa metode penggalian dan pengkategorian pelanggan ini dapat membatu mengatasi hambatan yang terjadi ketika Sales and Account Manager melakukan komunikasi persuasi. Adapun metode yang digunakan adalah metode NOSE. Metode ini merupakan kependekan dari Need (menggali kebutuhan pelanggan), Output (menemukan kebutuhan pelanggan), Solutions (Menentukan kebutuhan pelanggan) dan Evidence (Memberikan bukti kepada pelanggan). Dari temuan akan solusi tersebut, 
peneliti beranggapan bahwa dengan mengaplikasikan metode NOSE ini, akan membantu Sales and Account Manager dalam menentukan perangkat persuasi dan teknik persuasi yang dilakukan dalam mempertahankan pelanggan. Hal itu dikarenakan, hasil dari penggalian informasi dengan metode NOSE, maka Sales and Account Manager dapat mengenali dan memahami pelanggan, serta tahu persis bagaimana mengatasinya.

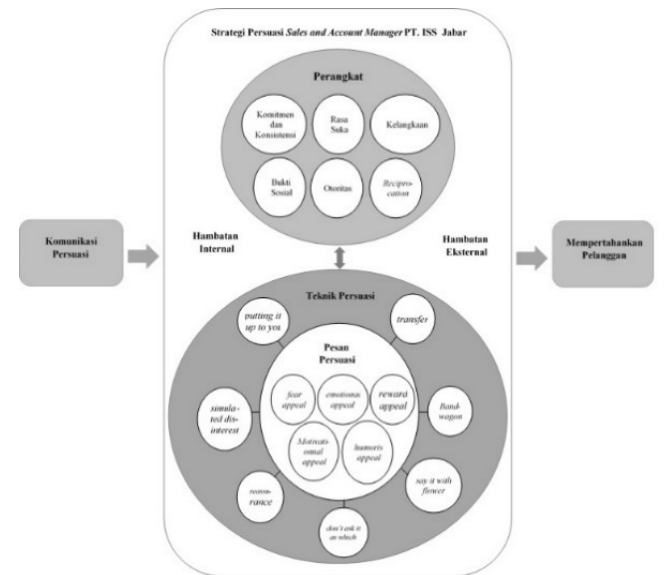

Gambar 14. Model Strategi

Komunikasi Persuasi Sales and Account

Manager dalam mempertahankan pelanggan

\section{Simpulan Dan Saran} yaitu:

Kesimpulan dari penelitian ini,

1. Komunikasi persuasi penting untuk dipahami oleh Sales and Account Manager dalam mempertahankan pelanggan karena pihak tersebut yang berhubungan langsung dengan konsumen dalam memberikan informasi mengenai produk, meyakinkan pelanggan untuk menggunakan jasa layanan yang disediakan, memperpanjang kontrak, dan mempromosikan jasa layanan PT ISS Jawa Barat pada kolega-kolega bisnis mereka. Memahami pentingnya komunikasi persuasi dalam mempertahankan pelanggan tidak saja diakui dan disadari oleh Sales and Account Manager, namun juga oleh Branch Business Manager, dan Service Manager.

2. Sales and Account Manager melakukan komunikasi persuasi kepada pelanggan melalui perangkat persuasi a) Reciprocation berupa respon yang cepat terhadap kebutuhan pelanggan dan kepedulian kepada pelanggan, untuk perangkat reciprocation, bentuk pemberian hadiah sebagai prinsip kebaikan dibalas kebaikan dilakukan dalam bentuk yang berbeda, b) Komitmen dan konsistensi dengan cara memberikan pelayanan sesuai dengan yang dijanjikan serta langkah-langkah yang dilakukan tetap stabil, dan berkesinambungan, c) Bukti sosial melalui penyebutan nama tokoh penting atau pelanggan yang terkait dengan ISS, beritaberita positif mengenai ISS di media seperti penghargaanpenghargaan yang telah dicapai, d) Rasa suka yang ditumbuhkan melalui tampilan sikap, perilaku maupun penampilan fisik, e) Otoritas dengan menyebutkan nama Elisa Lumbantoruan sebagai tokoh yang dianggap memiliki otoritas dan dijadikan nama rujukan saat melakukan persuasi kepada pelanggan, dan f) Kelangkaan dengan mengubah segmen dan spesialisasi.

3. Teknik persuasi yang dilakukan oleh Sales and Account Manager sangat beragam dan tergatung pada situasi dan 
kondisi di lapangan. Terdapat tujuh teknik yang dipakai oleh Sales and Account Manager, yakni teknik putting it up to you, teknik simulated disinterest, teknik transfer, teknik bandwagon, teknik say it with flower, teknik don't ask it as which, dan teknik reassurance. Pemilihan teknik yang digunakan berdasarkan pada kepekaan, pengalaman dan analisa hasil berlatih seorang Sales and Account Manager dalam menghadapi pelanggan. Teknik persuasi yang digunakan berkaitan erat dengan penyusunan pesan di dalamnya. Teknik penyusunan pesan yang digunakan adalah fear appeal, emotional appeal, reward appeal, motivational appeal, dan humoris appeal. Teknik penyusunan pesan memiliki keterkaitan dengan perangkat persuasi, atau dengan kata lain, teknik penyusunan pesan ada dalam perangkat persuasi yang digunakan.

4. Hambatan yang dihadapi Sales and Account Manager dalam melakukan komunikasi persuasi untuk mempertahakan pelanggan bersifat internal dan eksternal. Hambatan internal berkaitan dengan kondisi psikologis dari kedua belah pihak, sedangkan hambatan eksternal biasanya menyangkut masalah waktu, gangguan komunikasi, dan arus pesan. Adapun hambatan lain di luar konteks komunikasi adalah tentang harga yang tinggi dan persaingan. Sehingga, solusi yang dilakukan untuk mengatasi hambatan ketika melakukan komunikasi persuasi tersebut tidak hanya yang bersifat komunikasi saja, akan tetapi juga melalui metode NOSE.

\section{Saran}

1. Berdasarkan penelitian yang telah diteliti, bahwa perangkat, dan teknik persuasi serta teknik penyusunan dalam teknik persuasi telah dilakukan oleh Sales and Account Manager dan mendapat apresiasi serta pengakuan dari atasan langsung, mitra kerja serta pelanggan. Meskipun hambatan-hambatan yang terjadi dapat diatasi melalui beragam solusi, diharapakan Sales and Account Manager dapat terus mengembangkan kemampuan komunikasi persuasi secara terus menerus agar menjadi semakin handal, serta dapat melatih diri untuk mempelajari teknik lain di luar teknik yang sudah dilakukan.

2. Sales and Account Manager sebaiknya menggali literatur yang membahas tentang komunikasi persuasi.

3. Sebaiknya Sales and Account Manager terus melakukan inovasi dan menemukan strategi komunikasi persuasi yang baru agar ketika strategi yang telah digunakan tidak berhasil atau ditiru oleh kompetitor, PT ISS Jawa Barat masih memiliki alternatif sehingga pelanggan tetap loyal atau atau pelanggan baru dan calon pelanggan tertarik untuk menggunakan jasa layanan PT ISS Jawa Barat.

4. Bagi pihak-pihak lain yang terkait dengan tema penelitian yang penulis lakukan, disarankan untuk lebih fokus terhadap kegiatan komunikasi 
persuasi dan aspek lain yang terkait di dalamnya seperti teknik persuasi di luar yang disampaikan dalam penelitian ini.

5. Penelitian selanjutnya dapat menggunakan metodologi penelitian kualitatif dengan pendekatan fenomenologis, dengan contoh judul penelitian "konstruksi makna diri Sales and Account Manager ketika mempertahankan pelanggan".

6. Penelitian selanjutnya untuk menggunakan metodologi penelitian lain, seperti kuantitatif untuk mengukur hubungan atau pengaruh dari komunikasi persuasi Sales and Account Manager terhadap loyalitas pelanggan, dengan contoh judul "Pengaruh Komunikasi Persuasi Sales and Account Manager Terhadap Loyalitas Pelanggan".

\section{Daftar Pustaka}

Widjaja, A.W.. 2002. Komunikasi dan Hubungan Masyarakat. Jakarta: PT. Bumi Aksara

Cangara, Hafied. 2013. Perencanaan dan Strategi Komunikasi. Jakarta: PT Raja Grafindo Persada

Creswell, W John. 2010. Research Design: Pendekatan Kualitatif, Kuantitatif, dan Mixed. Yogyakarta: Pustaka Pelajar.

Mulyana, Deddy. 2001. Metode Penelitian Kualitatif. Bandung: Remaja Rosdakarya.

Soemirat, Soleh. 2014. Komunikasi Persuasif. Tangerang Selatan. Universitas Terbuka.

Yin, Robert. K. 2002. Studi Kasus: Desain dan Metode. Terjemahan. Jakarta: PT Raja Grafindo Persada

Yulianti. 2003. Interaksi Sosial Masyarakat Majemuk di Kalangan Elite. 